\title{
STUDENT-EDITED LAW REVIEWS: REFLECTIONS AND RESPONSES OF AN INMATE
}

\author{
NATHAN H. SAUNDERS
}

In the classic description, students without law degrees set the standards for publication in the scholarly journals of American law-one of the few reported cases of the inmates truly running the asylum. ${ }^{1}$

\section{INTRODUCTION}

The above epigraph represents but one example in a long line of attacks leveled at the institution of the student-edited law review. The mixed feelings of legal academics toward their scholarly journals ${ }^{2}$ may date to the inception of the student-edited review; at the least, they can be traced back to Fred Rodell's famous piece Goodbye to Law Reviews, published in the Virginia Law Review over sixty years ago.

Interestingly, however, the average law student will likely hear none of this criticism. Indeed, the average law student's ignorance on the topic may continue well into her own legal education, perhaps as long as or longer than my own did-halfway through my second se-

* I would like to thank most sincerely the members and editors of Volumes 48 and 49 of the Duke Law Journal, who, individually and collectively, have enriched my law school experience beyond measure, as well as Professor Jeff Powell, whose excellent seminar on the culture of American law provided the starting point for this Note.

1. John G. Kester, Faculty Participation in the Student-Edited Law Review, 36 J. LEGAL EDUC. 14, 14 (1986); accord Arthur D. Austin, The "Custom of Vetting" as a Substitute for Peer Review, 32 ARIZ. L. REV. 1, 4 (1990) ("The use of student edited journals as the main outlet for legal writing is an embarrassing situation deserving the smirks of disdain it gets from colleagues in the sciences and humanities."); James Lindgren, An Author's Manifesto, 61 U. CHI. L. REV. 527, 527 (1994) ("Our scholarly journals are in the hands of incompetents."). Perhaps the most famous critique of the student-edited law review was penned by legal realist Fred Rodell: "Maybe one of these days the law reviews, or some of them, will have the nerve to shoot for higher stakes. ... Meanwhile I say they're spinach." Goodbye to Law Reviews, 23 VA. L. REV. 38, 45 (1936).

2. Even the harshest critics of the student-edited law reviews, such as Professors Rodell and Lindgren, both cited supra note 1 , frequently publish in the very targets of their criticism, betraying their implicit acknowledgment that this format has at least some benefits. 
mester as a staff editor on the Duke Law Journal. Not until I took a relatively nontraditional seminar in which we read Professor Rodell's essay did I become aware of the disdain that my colleagues and I suffer from many of our potential (and perhaps even our actual) authors. At the same time, I also became keenly aware of the potential power that I, as a newly elected article editor of Volume 49, might soon be tempted-or ignorant enough—-to wield abusively.

Realizing the unique position I was in, I felt both a responsibility and an interest in investigating what else, if anything, had been written on the subject. I found no shortage of materials on the topic, all of which were fascinating reading and very instructive to me as a new article editor. At least three symposia and one exchange on this subject have been published in the last six years, ${ }^{3}$ as well as numerous independent articles and essays featuring criticisms of the current law review system, ranging from constructive ${ }^{4}$ to politely scathing. ${ }^{5}$ Some professors even defend law reviews against their critics. ${ }^{6}$ Student editors have entered the debate, generally rejecting criticisms or shifting the blame, ${ }^{7}$ but often admitting the need for reform. ${ }^{8}$

3. See Symposium, Law Review Conference, 47 STAN. L. REV. 1117 (1995); Symposium on Law Review Editing: The Struggle Between Author and Editor over Control of the Text, 70 CHI.KENT L. ReV. 71 (1994); Symposium, Who Needs Law Reviews?: Legal Scholarship in the Age of Cyberspace, 30 AKRON L. REV. 173 (1996); Exchange, 61 U. CHI. L. REV. 527 (1994) (featuring essays by James Lindgren, Wendy J. Gordon, and the University of Chicago Law Review articles editors).

4. See, e.g., Ann Althouse, Who's to Blame for Law Reviews?, 70 CHI.-KENT L. REV. 81, 83 (1994) (suggesting that authors' displeasure with student editing should translate into a critique of the authors' own writing); Lindgren, supra note 1, at 537-39 (listing nine suggestions for reform-minded student-edited law reviews).

5. See, e.g., Bernard J. Hibbitts, Last Writes? Re-assessing the Law Review in the Age of Cyberspace, 30 AKRON L. REV. 175 (1996) (abstracting Hibbitts's article of the same title, originally self-published on the World Wide Web in February 1996 and later reprinted, ironically "with further revisions," id. at 175 n.1, in 71 N.Y.U. L. REV. 615 (1996)); Richard A. Posner, The Future of the Student-Edited Law Review, 47 STAN. L. REV. 1131 (1995).

6. See, e.g., Richard Delgado, Eliminate the "Middle Man"?, 30 AKron L. REV. 233 (1996); Wendy J. Gordon, Counter-Manifesto: Student-Edited Reviews and the Intellectual Properties of Scholarship, 61 U. CHI. L. REV. 541 (1994) (responding to Professor Lindgren's Manifesto); Leo P. Martinez, Babies, Bathwater, and Law Reviews, 47 StAN. L. REV. 1139 (1995).

7. See Articles Editors, A Response, 61 U. CHI. L. REV. 553 (1994) (responding to Professor Lindgren's Manifesto); David S. Friedman et al., Editors' Forum, 47 STAN. L. REV. 1157 (1995) (featuring short comments from six law review editors who attended Stanford's Law Review Conference).

8. See Articles Editors, supra note 7, at 553 ("A better way to respond to Lindgren's concerns ... would be to institute moderate reforms of the current 'market' in law review services."); The Executive Board of the Chicago-Kent Law Review, The Symposium Format as a Solution to Problems Inherent in Student-Edited Law Journals: A View from the Inside, 70 CHI.KENT L. REV. 141 (1994) (endorsing the symposium format as an appropriate solution to the problems of student-edited law reviews). 
In this Note, I acknowledge that student-edited law reviews have inherent flaws, and that many of the widespread criticisms are valid ones. ${ }^{9}$ In general, however, the problems noted are so deeply rooted in the system that they cannot be completely solved without undermining the many benefits that accompany student-edited reviews. Thus, I argue that the benefits of student-edited law reviews to legal education, legal scholarship, and the legal profession are important enough that the institution of student editing should remain, with a few constructive reforms.

In Part I, I outline what I perceive to be the three principal criticisms of student-edited law reviews: elitist selection practices, the relative scholarly incompetence of student editors, and excessive editing by multiple editors-what Carol Sanger has called the "multilayered attack" on the author's draft. ${ }^{10}$ In Part II, I balance this with a discussion of the benefits that the institution of student-edited law reviews brings to student editors, faculty, and later employers-primarily, a strong supplement to the editors' legal education, increased opportunity for student-faculty interaction, and greater freedom for law professors. In Part III, I discuss what I believe to be the general problem underlying the various deficiencies in the current system: the dominance of hierarchy, not only in the culture of law reviews, but in legal culture generally. Admitting that there is no solution to this underlying problem, I explore in Parts IV and V some suggestions for reform. Though I reject some of these suggestions, I believe that many could be both workable and beneficial, such as returning control of the work to the author, diversifying membership criteria, encouraging informal faculty involvement, and instructing student editors in editing.

\section{CRITICISMS OF THE CURRENT SYSTEM}

\section{A. Elitism and Selection Practices}

When I first arrived at the Duke Law Journal offices for my orientation as a staff editor in August 1998, manuscript review was in

9. My focus in this Note is on student editing of articles and essays written by law professors and practitioners, rather than of student notes. The principal reason for this is that student editing of another student's work is a form of peer editing, and thus does not create the same unique and problematic role reversals that student editing of professors' or practitioners' writing does.

10. Carol Sanger, Editing, 82 GEO. L.J. 513, 523 (1993). 
full swing. I was amazed at the sheer volume of articles stacked on our shelves, to be read and evaluated by the four article editors. How, I asked, could they possibly review them all? An uncomfortable snicker accompanied the response: "We don't."

Later, when I was elected article editor and began reviewing articles on my own, I quickly learned the shortcuts to article selection: Review articles from top schools and top professors quickly, not because they are necessarily better, but for practical reasons-that is, because another law review is much more likely to grab them up. Take at face value the staff editor and editorial board "screening" reviews of articles, ${ }^{11}$ and don't waste time on anything that did not receive a superlative evaluation. Finally, and most importantly, let the editors of other law journals do your work for you; that is, concentrate your effort on expedited reviews-articles which have already received an offer from another journal. ${ }^{12}$

Top-tier law reviews frequently receive over one thousand submissions per volume. ${ }^{13}$ Although we do not keep an official count at

11. At the Duke Law Journal, all staff editors must "screen" one to three articles a week during the peak article selection periods. They read the article and write a short summary of its argument and its quality. Finally, they assign the article a quality/desirability score on a scale of 1 to 10 .

12. When a law review gives an offer to publish to an author, the author typically calls other law reviews in which she would prefer to publish to request that her article receive an expedited review. This alerts editors at the preferred law review that the article is probably worth publishing (since the editorial board of a competing law review clearly believes so). The currency carried by an in-hand offer frequently allows the author to "trade up" to a more prestigious law review. See Erik M. Jensen, The Law Review Manuscript Glut: The Need for Guidelines, 39 J. LEGAL EDUC. 383, 384-85 (1989) (outlining the expedited review process, which, although "demeaning ... to an author," often "results in placement in a higher journal-and thus in upgrading the author's reputation").

13. See id. at 383; Jordan H. Leibman \& James P. White, How the Student-Edited Law Journals Make Their Publication Decisions, 39 J. LEGAL EDUC. 387, 416 (1989). Leibman and White arrived at this figure by surveying 13 of the 19 most-cited law reviews according to a 1976 study by Olavi Maru. See id. at 393 \& n.30 (citing Olavi Maru, Measuring the Impact of Legal Periodicals, 1976 AM. B. Found. REs. J. 227, 233 (1976)). Leibman and White's list of "highimpact" journals consists of the general law reviews from several schools from the top tier of American law schools, as ranked yearly by U.S. News and World Report. See id. See generally Exclusive Rankings-Schools of Law, U.S. NEWS \& WORLD REP.: BEST GRADUATE SCHOOLS (2001), at 49-52 (available online at U.S. News's website (visited Apr. 15, 2000) <http://www. usnews.com/usnews/edu/beyond/gradrank/law/gdlawt1.htm> (on file with the Duke Law Jour$n a l)$.

A more recent, oft-cited survey of "top-tier" law reviews is the Chicago-Kent Law Review's Faculty Scholarship Survey, which, like Maru's 1976 study, ranks law reviews according to their frequency of citation in other law reviews. See Colleen M. Cullen \& S. Randall Kalberg, Chicago-Kent Law Review 1995 Faculty Scholarship Survey, 70 CHI.-KENT L. REV. 1445, 1452 tbl.1 (1995). It bears noting that the impetus for Chicago-Kent's original Faculty Scholarship Survey, see The Executive Board of the Chicago-Kent Law Review, Chicago-Kent Law Review 
the Duke Law Journal, based on the experiences of my colleagues and myself over the past year, this estimate seems, if anything, to be a conservative one. ${ }^{14}$ Since editing a law review is a part-time job, and since that job requires much more of article editors than simply reviewing submissions, the shortcuts that article editors use are essential to managing the volume of manuscripts received by a law journal. ${ }^{15}$

Many commentators criticize the widespread practice of favoring submissions by professors from prestigious law schools or famous authors, and the failure to give full attention to all submissions. ${ }^{16}$ Admittedly, these faults necessarily accompany the dominant selection practices of most student-edited law reviews. However, though these criticisms are valid-some diamonds in the rough will inevitably get passed over-I argue below that problems of elitism and competitiveness are so deeply rooted that the prospect of eliminating them from student-edited law reviews is dismal, if not nonexistent. ${ }^{17}$

\section{B. Scholarly Incompetence}

An additional problem with the system of student-edited law reviews, as Professor Lindgren baldly asserts in his Author's Manifesto, ${ }^{18}$ is that law students are not as knowledgeable as law professors. As a result, Lindgren points out, student editors "often select articles with-

Faculty Scholarship Survey, 65 CHI.-KENT L. REV. 195 (1989), was to evaluate whether Chicago-Kent's own standing had improved as a result of their 1987 switch from a student-edited general law review to a faculty-edited "all-symposium" format. See Cullen \& Kalberg, supra, at 1445; see also infra notes 59-61 and accompanying text (discussing the Chicago-Kent Law Review's change in format).

14. Our managing editor confirms this; he estimates that during Volume 49's article review season, which began in March 1999, shortly after our board was elected, and ended about 10 months later when had we filled our six issues, we received between 1400 and 1500 articles and essays for consideration.

15. See Jensen, supra note 12, at 385 (suggesting that owing to the "submissions glut," "student editors' overreliance on authors' credentials is quite reasonable").

16. See, e.g., Leibman \& White, supra note 13, at 405 ("[T] he lack of blind review seriously compromises the credibility of the manuscript review process."); Lindgren, supra note 1, at 530 (noting abuses in the student editing process, including using "the school of the submitter [as] a major consideration in deciding what to accept"). But see Posner, supra note 5, at 1133-34 (suggesting that the "reputation of the author" may be an appropriate trademark of quality for student editors, who frequently are not "competent to evaluate nondoctrinal [legal] scholarship"). On the scholarly competence of student editors, see infra Part II.B.

17. See infra Part III.

18. See Lindgren, supra note 1, at 527 ("Our scholarly journals are in the hands of incompetents."). 
out knowing the subject, without knowing the scholarly literature, [and] without understanding what the manuscript says."

This problem is incurable, short of completely overhauling the model of student-edited law reviews. ${ }^{20}$ However, since this problem is central to the institution of student-edited law reviews, student editors are hardly unaware of it. Indeed, numerous symposia, articles, and essays, cited throughout this Note, have been published in recent years debating the merits of the current law review system. Naturally, the majority of these discussions, like the majority of legal scholarship in general, have been published by student-edited law reviews. This seems to indicate that most law review editors are not ignorant of their peculiar position in the legal academy, and conscientious editors strive to improve the system.

For example, at the elections for the Volume 49 executive board of the Duke Law Journal, a conscious effort was made to elect a class of article editors with diverse scholarly interests and expertise. Even though student editors generally know far less about any given topic than does a professor who has studied and written about the same area, a deliberate attempt to elect a set of article editors with diverse knowledge at least increases the chances that a given submission can be evaluated or edited by a relatively knowledgeable and competent student editor. And finally, at the Duke Law Journal, editors frequently seek the opinion of faculty members when we are uncertain about the merits of a particular article or its place in the context of prior scholarship. ${ }^{21}$

\section{Excessive Editing-Incompetence atop Incompetence}

In her essay, Professor Sanger vividly expresses the problems associated with student editing: "Too often ... law review articles are not so much improved as simply changed, sometimes hundreds of times within a single manuscript." ${ }^{, 22}$ Student editing may not be constructive — and may even be destructive-for two main reasons. First, as Professor Lindgren notes, student editors of law reviews frequently

19. Id.; accord Richard A. Epstein, Faculty-Edited Law Journals, 70 CHI.-KENT L. REV. 87, 88 (1994) (observing that student editing is "hampered by limitations that stem from [students'] inexperience in dealing with substantive issues"); Posner, supra note 5, at 1133.

20. And many critics of the current system advocate exactly that. See infra Parts IV.A-B.

21. On the benefits of interactions between student editors and faculties, see infra Part II.B. For my argument for informal faculty involvement in law reviews, see infra Part V.B.

22. Sanger, supra note 10 , at 513 . 
have no training and no supervision in the editing process. ${ }^{23}$ Second, the hierarchy of law review editors often renders the editing process a "multilayered attack on the draft by which editor after editor in the review hierarchy rethinks the commas and reassesses the arguments," often "opening matters already debated and resolved." 24

This "multilayered attack" on a manuscript, which I call "serial editing," is intended to divide labor and compartmentalize the editing process. In theory, serial editing will increase the consistency and overall quality of the finished product via specialization. ${ }^{25}$ However, when serial editing is not well executed, or when a weak link is present in the hierarchy of editors, serial editing can render a piece at best diluted, and at worst incoherent. ${ }^{26}$

23. See Lindgren, supra note 1 , at 527-28 (citing his own inexperience as a student editor and criticizing the professoriat for not supervising law review editors). But see Phil Nichols, Note, A Student Defense of Student Edited Journals: In Response to Professor Cramton, 1987 DUKE L.J. 1122, 1128-32 (defending student law review editing). Nichols-editor-in-chief of the Duke Law Journal for the 1987 volume-argues in his note that

[t]here is no reason to believe that law school students cannot edit. Law school students are all college graduates, and in general have high verbal skills. Those selected for law review, by whatever method, also exhibit some ability to organize thoughts and express them clearly. All of these qualities are the essential skills for editing qua editing.

Id. at 1129 (footnote omitted). Nichols then goes on to point out that law students may in fact be uniquely suited to edit legal scholarship:

[I]t is important that law review material be accessible to [a wide] audience. Therein lies the value of student editors. Students are less specialized than they will ever be again, possessing the fundamentals of legal reasoning without years of exposure to only one or two branches. An article that makes sense to a student editor will make sense ... to any academic [or practitioner], no matter how specialized that [individual] has become.

Id. at 1130 (footnote omitted).

24. Sanger, supra note 10, at 523.

25. Duke Law Journal pieces undergo serial editing as follows. First, the article editor works through two rounds of edits with the author. The research editor also participates in these edits, suggesting where the author might need additional support. After the author responds to these suggestions and submits the final version of her piece to the Duke Law Journal, the piece is citechecked by staff editors, then reviewed again by the research editor. The ostensible purpose of this "research edit" is to check the work of the citecheckers. However, additional author queries invariably arise, usually resulting in another round of citechecking. Next, the piece is checked in turn by the executive editor and the editor-in-chief, principally for publication style, mechanics, and a final read. Again, however, suggestions for substantive changes often arise. As a result, when the author gets her article back in page-proof form for her final approval, it can often be very different from the "final version" she submitted to the article editor just prior to citechecking. See also infra Part V.E (discussing house publication style, and suggesting that employing redlined versions of an author's work may be an appropriate means of facilitating author review of the final version).

26. A weak link, a breakdown in communications, or a "bottleneck" (when, for example, several pieces reach a certain editor at the same time) may also cause severe publication delays. 
To illustrate the problems with student editing from the perspective of the authors, Professor Lindgren offers the following analogy to student law review editors "perplexed by the hostility that their incompetence generates." ${ }^{27}$ Lindgren's hypothetical, though perhaps hyperbolic, is so effective that I feel I can only do it justice by quoting it at length:

Imagine that as a law student, you had spent many months writing what you believed would be a fine student note, a note that you hoped would land you a managing board position, a good clerkship, and ultimately perhaps a job. Then imagine that before you could submit this note, you had to give it to a group of bright high-school students who rewrote almost every sentence. Even if you were able to struggle through the process and talk them out of dozens of stupid mistakes, the resulting product would little resemble the work that you were so proud of. This is what it feels like. And it doesn't happen just once, it happens almost every time we publish. ${ }^{28}$

\section{BENEFITS OF THE CURRENT SYSTEM}

\section{A. Student-Edited Law Reviews as a Supplement to Legal Education}

Though the current system poses many problems, it also provides significant benefits to student editors, law faculty, and future legal employers. The first and most tangible benefit provided by studentedited law reviews is that they are an excellent supplement to a legal education. ${ }^{29}$ For student editors, participation in law review hones skills of legal argument and legal writing, teaches familiarity with Bluebook citation style, and indoctrinates the student with a general attention to detail that is extremely valuable in legal practice. Judge John Noonan argues that the education by peers provided by studentedited law reviews is "the best-I am tempted to say the only-kind of education." ${ }^{30}$ Noonan believes that "to enter the heart of a discipline such as law, one has to exchange ideas ... argue for ideas, and

27. Lindgren, supra note 1 , at 540.

28. Id.

29. See Gordon, supra note 6, at 543 ("[M]ost student editors consider their review work a valuable learning experience.... Membership on a law review is one of the few forms of apprenticeship left in our profession."); Martinez, supra note 6, at 1140 ("Use of law reviews is a means to a pedagogical end-the training of students in careful, albeit anally retentive, reading of minutia.").

30. John T. Noonan, Jr., Law Reviews, 47 STAN. L. REV. 1117, 1118 (1995). 
point out to others the logical implications, the missing factual foundations, and the underlying assumptions of their ideas." ${ }^{11}$

This has certainly been my experience on the Duke Law Journal. As a staff editor, I often found myself in deep discussions with an article editor, a research editor, or another staff editor about the best way an author could use a source to support his assertion, or about the clearest and most logical form for a unique citation, or (outside of the editing process) about the substantive and theoretical issues raised by a forthcoming article. The serious debates the article selection committe ${ }^{32}$ has had during my tenure as article editor over whether to extend offers to authors have been among the more intense and rigorous academic debates I have engaged in during law school. ${ }^{33}$ Finally, the exposure to many different fields of legal scholarship, many different legal writers, and many different specific ideas that I have gained through editing and citechecking articles and screening dozens of submissions has contributed greatly to the depth and breadth of my legal education.

Another educational benefit, though perhaps pedantic and fetishistic, is facility with the Bluebook. This benefit is of course a direct result of uncountable hours spent editing and citechecking. The internalization of such a complex citation system enables a legal writer to think in footnotes - that is, to compose sophisticated below-the-line support with the same relative ease with which he drafts above-theline argument. ${ }^{34}$ In fact, I am now able to compose (and citecheck for form) most footnotes without any reference at all to the Bluebook. This ease of composition streamlines the legal writing process considerably, and this skill, along with the general attention to detail that training in citechecking and line-editing develops, will no doubt be highly valued by future employers and clients. Finally, the development of citation and editing skills is an important benefit that accrues to all law review participants, not merely to those elected to editorial

31. Id.

32. For Volume 49 of the Duke Law Journal, the article selection committee consists of the four article editors, the editor-in-chief, and the two executive editors.

33. Since a unanimous vote is required from the selection committee before the editor-inchief will extend an offer to publish in the Duke Law Journal, many of the deliberations, particularly over articles strongly supported by one or two committee members, have been very deep and heated.

34. But see Richard A. Posner, Goodbye to the Bluebook, 53 U. CHI. L. REV. 1343, 1349 (1986) (arguing that the Bluebook's obsession with form is to blame for legal writing's "dismal sameness of style" and "drab, Latinate, plethoric, euphemistic style"). 
positions in their third year, or to those who publish their student notes.

\section{B. Student Interaction with Legal Scholars}

Another major benefit of the system of student-edited law reviews is that it promotes the interaction of students with legal scholars. Law review editors are afforded significant opportunities to work with law professors. At the Duke Law Journal, for example, each second-year staff editor works closely with a faculty advisor in developing and writing a student note. In addition, student editors often bring submitted articles to professors to discuss the ideas and arguments advanced by the author. Since the prestige of a law review, like the prestige of any component part of an institution, contributes to the prestige of the law school and the university, faculties and individual professors have incentives to provide assistance to their school's law review whenever their schedules allow. During the tenure of our board, professors at Duke Law School have generously provided assistance when asked. My experience leads me to believe that informal faculty involvement with student-edited law reviews is positive for all parties, and I endorse this particular reform below. ${ }^{35}$

Law review editors also have the opportunity (and the responsibility) to deal with authors who represent the faculties of other law schools. It is not unusual for a journal's reputation to grow from these interactions. Even in rejecting submissions, professional conduct may increase a law review's reputation. For example, one professor accepted our board's offer of publication on the recommendation of a colleague who had been impressed with how we conducted an expedited review for him earlier in the year. Finally, the close interaction of authors and student editors during the editing and publication process also cultivates professionalism, a valuable skill in the often adversarial and unfriendly legal industry.

\section{Benefits to Law Faculties}

Finally, the system of student-edited law reviews frees up faculty time. ${ }^{36}$ This additional time improves teaching and faculty-student interaction-qualities that law faculties, more than many other gradu-

35. See infra Part V.B.

36. Cf. Martinez, supra note 6, at 1144 ("[F]aculty are busy .... Time pressures would not allow most to be active contributors to [faculty-edited law journals]."). 
ate faculties, value highly. More time for professors to invest in writing may also increase both the quality and the quantity of legal scholarship. Similarly, greater freedom enables law professors to spend time in other productive ways, such as doing more pro bono or charitable work, thus providing a tangential benefit to society in general. In sum, and speaking somewhat cynically, faculties may be reluctant to forego the cheap labor of student editors. ${ }^{37}$ Doing so might reduce the time they can spend with their families or on original writing and academic work, undermining a significant reason qualified attorneys may pursue a job teaching rather than working for the huge salaries paid at Silicon Valley and New York City law firms.

\section{Assistance to Employers in the Hiring Process}

As some commentators have cynically noted, positions on law review-particularly on the third-year executive board-assist employers in determining who are the most desirable candidates in a particular class. ${ }^{38}$ Admittedly, receiving a law review position by itself is not a significant indication of a student's merit, because it merely indicates first-year accomplishments in the same way that first-year grades or samples of legal writing do. Absent student-edited law reviews (indeed, absent law reviews altogether), legal employers would simply assign greater weight to other indices of success: the quality of the law school attended, grade point average and class rank, the rigor of the student's course of study, and, in some cases, undergraduate college attended and area of study. However, even if a law review position by itself does not add anything unique to a job candidate's desirability, employers correctly view law review participation, including executive board positions and note authorship, as evidence that a student is dedicated enough to work diligently on a rigorous and challenging project.

37. See Articles Editors, supra note 7, at 555 ("Most faculty ... prefer writing to supervisory work, and it would be hard for law reviews to offer them compensation sufficient to induce them to redirect their efforts. Perhaps student freedom from faculty oversight persists simply because student labor is cheap.").

38. See, e.g., James D. Gordon III, How Not to Succeed in Law School, 100 YALE L.J. 1679, 1700 (suggesting humorously that law review editors "are given this special honor so that employers will not overlook them just because they are at the top of their class"); Rodell, supra note 1, at $44-45$ ("The students who [work] for the law reviews are egged on by the comforting thought that they will be pretty sure to get jobs when they graduate in return for their slavery ...."). 


\section{ThE UndERLYING PROBLEM: COMPETITION AND HIERARCHY}

\section{A. Hierarchies Are Omnipresent}

The problems of student-edited law reviews stem in part from the arrogance of student editors- "the big snots around the school.",39 This arrogance seems inevitable given the "best of the best" selection criteria used in tapping students for law review membership. Leo Martinez likens student editors to the Mercury astronauts as depicted in Tom Wolfe's novel The Right Stuff-talented persons "lavished with riches based not on actual accomplishments but [on] the potential each ha[s] to accomplish greatness." Given this "blazing aura" of greatness, Martinez argues, "it would be surprising if law review editors did not develop a certain amount of arrogance."

Another factor contributing to the arrogance of law review editors is the incredible amount of power they wield, both over the directions of legal scholarship, and, more to the point, over legal scholars. As Professor Sanger succinctly put it, "in what other discipline do students determine the shape of professorial careers?"43

However, this arrogance of law review student editors is far from the only instance of constructed prestige and hierarchy within American legal culture. Academic snobbery and prestige wars are endemic not only to law reviews, but to the legal academy as a whole, ${ }^{44}$ the legal profession, ${ }^{45}$ and Western society generally. ${ }^{46}$ First-year law students are immediately dropped into one of the most highly competitive environments in our society, and most of them look forward to practicing in one of the most fierce and competitive industries in

\footnotetext{
39. Gordon, supra note 38 , at 1700.

40. Martinez, supra note 6 , at 1140.

41. Tom Wolfe, The Right Stuff 100 (Bantam Books 1983).

42. Martinez, supra note 6, at 1140 .

43. Sanger, supra note 10 , at 517.

44. See, e.g., Duncan Kennedy, Legal Education and the Reproduction of Hierarchy: A Polemic Against the System 73-97 (1983) ("The attitudes, behaviors and relationships associated with legal hierarchy constitute, in themselves, a social perversion.").

45. For example, virtually all law firms are structured hierarchically, with a person's rank, power, and compensation tied to a number of factors-most prominently, seniority, hours billed, and clients recruited.

46. See, e.g., KENNEDY, supra note 44, at 84 ("Legal hierarchy is a typical American phenomenon, rather than something peculiar to law or even to the professions."); Brian Tierney, Hierarchy, Consent, and the "Western Tradition", 15 POL. THEORY 646, 646-47 (1987). Critical Legal Studies theorists examine the interaction of cultural hierarchies with the law. See generally JAMES BOYLE, CRITICAL LEGAL STUDIES (1994) (collecting legal scholarship in the field).
} 
America. In between, newly selected law review editors are told by faculties that they have emerged from the first year the best and brightest of their class, just as law firm recruiters openly label them the most promising and most desirable candidates at the school.

Neither the student editors nor the law reviews themselves are to blame for this awareness of hierarchy and prestige. Consider the hierarchies a law student must contemplate just during his law school career: LSAT scores, applicant group admissions charts showing the LSAT scores and GPAs of applying and admitted students, ${ }^{47}$ US News and World Report's law school rankings ${ }^{48}$ (of concern while applying to, while attending, and after graduating from law school), first-year grades (of concern for determining law review membership as well as during the recruiting season), and the American Lawyer's top 100 law firms rankings (which rank large law firms by numerous categories, including firm income, firm profitability, profits per partner, starting salary, and profits per transaction). ${ }^{49}$ Students are consistently (if implicitly) taught to wear their law school, their GPA, and their position on law review as a badge of their success and their worth; consequently, law review editors read others' badges (such as the law school of submitting authors) in the same way. ${ }^{50}$

This hierarchy results in fierce competition among different law reviews as well, which fight to publish the best legal scholarship in order to increase the prestige of the review and their law school. Professor Rodell wrote that law reviews "have all been sucked into a polite little game of follow-the-leader with the Harvard Law Review setting

47. See Law School Admission COUNCIL, The OfFICIAL Guide TO U.S. LAw Schools 65-427 (2000 ed. 1999) (reprinting statistical profiles of the 1998-99 applicant pools for each ABA-approved law school). These admissions charts are frequently used by law school applicants to gauge their own individual likelihood of acceptance at a given law school.

Another, less formal arena where grades and LSAT scores are used as a stand-in for merit and potential is the Princeton Review website at www.review.com. During the winter admission season, many discussion threads in the law school pages consist of cascades of terse messages from students admitted to a particular law school who anonymously (and hence unverifiably) post their own GPAs, LSAT scores, and other relevant basic information (usually ethnic group and gender). The intended purpose behind these discussion threads appears to be to allow students awaiting admission decisions (or dealing with recent rejection) to attempt to evaluate via anecdotal evidence current admission trends as they develop. See generally Law Discussion Area: Law School and LSAT Discussion Group (visited Apr. 5, 2000) <http://discuss. review.com/forums/index.cfm?cfapp $=6>$ (on file with the Duke Law Journal).

48. See generally Exclusive Rankings-Schools of Law, supra note 13.

49. See The Am Law 100, THE AMERICAN LAWYER, July 1999, at 95-145.

50. See Ronald J. Krotoszynski, Jr., Legal Scholarship at the Crossroads: On Farce, Tragedy, and Redemption, 77 TEX. L. REV. 321, 329-31 (1998) (discussing "the elaborately structured hierarchy which pervades the article selection process" at student-edited law reviews). 
the pace." ${ }^{51}$ That was in 1936. In 2000, about the only thing that has changed is that the prestige game is no longer quite so polite.

\section{B. Collective Action Toward Reform Is Not Possible}

This dominant culture of prestige and hierarchy is the reason that many of the proposed solutions to the problems associated with student editing are not feasible. To truly bring about any lasting change to the current system, reforms, such as instituting blind review of articles and restricting submissions of articles to only one or to only a few law reviews at a time, must be adopted universally. However, given the highly competitive nature of law review publishing, no review is willing to be the first to adopt reforms, for fear that they will suffer relative to other reviews.

Similarly, the struggle to climb the law review hierarchy drives student editors to assert as much control over the author's text as possible, in a stubborn and perhaps ill-advised attempt to improve the review's content. But as noted above, the underlying hierarchy of law reviews will not permit substantial policy reforms in the system of student editing, since most meaningful improvements would require student editors to forego some of the control over the final product that their predecessors have seized. This, a typical editor might believe, would reduce the quality of the finished product and thus cause the review to lose prestige relative to other reviews and slip down the hierarchy.

Given every law review's desire to enter (or remain in) the top tier-an end predictably seen as identical with success-any reform that may reduce a review's chances of publishing prestigious authors and authors from prestigious schools will have to be enacted from the top down. The same is true of any reform of the student editing process that results in less control for student editors. But the top law reviews have very little incentive to make changes to improve their selection processes or their editing; since top reviews occupy wellentrenched positions of prestige, authors are eager to publish with them despite any problems they may encounter with their student editors. Authors are thus unlikely to exert pressure on top law reviews to improve their editing or selection processes. And as long as the top law reviews refuse to reform their selection and editing proc-

51. Rodell, supra note 1 , at 44 . 
esses, lower-ranked law reviews, desperate to compete, will not dare to do so either.

Furthermore, even if the top reviews did adopt blind review policies or other reforms, the aspirations of less prestigious reviews to compete with the top reviews would still prevent them from following suit. More likely, a less prestigious review would see the top reviews' new policy as an opportunity; a chance to gain some ground on the top reviews by acquiring some articles from Harvard and Yale professors who normally only publish in Harvard Law Review or Yale Law Journal. In short, as a direct result of the firmly entrenched hierarchy of law reviews, collective action among law reviews to reform student editing and article submission processes is impossible.

\section{MISGUIDED PROPOSALS}

I have argued that the root of the problems associated with student-edited law reviews is not the student editors or the student law review institutions alone, but rather underlying constructions of prestige and hierarchy prevalent in legal culture. The pressures this omnipresent hierarchy exerts on law review editors guarantees that many reforms requiring collective action will be impossible to effect. Instead, any workable reforms to the current system must improve the system and its processes without upsetting the deeply rooted (though perhaps unfortunate) perceptions of relative prestige that exist within the culture of law schools and law reviews. Many of the reforms proposed by commentators do not meet this criterion, and as a result I believe they are misguided.

\section{A. Peer-Edited Journals}

One obvious solution to the problems associated with studentedited law reviews is for faculties to take the initiative to start more peer-edited journals, ${ }^{52}$ such as the Journal of Legal Studies, founded by Richard Posner. ${ }^{53}$ Alternatively, some suggest that law faculties

52. See, e.g., Lindgren, supra note 1, at 536 ("[Faculties] should be willing to take on the substantial work of starting faculty journals.... [T] hey are almost uniformly better-edited than student journals.").

53. The Journal of Legal Studies is currently edited by Professors William M. Landes and Eric A. Posner, both of whom are faculty members at the University of Chicago Law School. For more information on The Journal of Legal Studies, see Journal of Legal Studies (visited Apr. 21, 2000) <http://www.journals.uchicago.edu/JLS/home.html> (on file with the Duke Law Journal). 
should take a more active role in current student law reviews-perhaps reviewing submissions and making publication decisions, and leaving the editing and production to the student editors. ${ }^{54}$

These suggestions sound appropriate but do not lead to a desirable solution. First, if these models were wholly to supplant the current model, the significant benefits of student-edited law reviews would be undermined. Faculty will have to invest a great amount of time in the new journals, something they may be unwilling to do. ${ }^{55}$ Also, the decline in student control will result in a decline in the educational benefits of law reviews, and may result in student editors dedicating less effort to their jobs. ${ }^{56}$

In addition, it is unlikely that new faculty-edited journals will ever compete with the top tier of student-edited journals, which have long histories and are afforded much prestige by the legal community. Some tenured professors who seek to retain maximum control of their articles and have no worries about increasing their own currency may prefer the editorial freedom allowed by faculty-run journals. But there will still be plenty of young professors seeking to gain prestige, better appointments, and ultimately tenure, who will subject themselves to the difficult editing process at student-edited law reviewsin particular, at the most prestigious journals, which are studentedited.

At best, therefore, creating more faculty-edited journals is only a partial fix. ${ }^{57}$ Top professors, whose work existing law reviews often

54. See, e.g., Randy E. Barnett, Beyond the Moot Law Review: A Short Story with a Happy Ending, 70 CHI.-KENT L. REV. 123, 131 (1994) (advocating that less prestigious journals consider moving to a faculty-edited symposium model as a means of improving the quality, and hence the standing, of the journal); Lindgren, supra note 1, at 535 (same). On the faculty-edited symposium format, see also infra Part IV.B (discussing in particular the Chicago-Kent Law Review).

55. See Martinez, supra note 6, at 1144 ("[F]aculty are busy .... Time pressures would not allow most to be active contributors to [faculty-run journals]."); see also supra Part II.C (noting that student-edited law reviews enable law professors to devote more time to teaching, scholarship and pro bono activities). But see Epstein, supra note 19, at 94 (arguing that "the work load [of faculty-run journals] can be kept to tolerable levels" by hiring professional editorial staffs).

56. See Articles Editors, supra note 7, at 555 ("[S]ome measure of authority and responsibility is an important incentive to do better work.").

57. One additional criticism of faculty-edited journals is that they may see increased opportunities for nepotism in their selection processes. This is more likely at faculty-edited law journals, since professors tend to develop ongoing relationships with other scholars whose work they will be evaluating. In contrast, this brand of nepotism would virtually never arise at a studentedited law review, whose senior editors are not established academics and, moreover, enjoy a tenure of only one year. But even insofar as opportunities for nepotism exist for faculty law review editors, the situation is likely no worse than student editors' incentives to afford nepotism to professors from their home school or their tendency to favor submissions from big-name pro- 
fight to publish in order to increase their currency and prestige, would have more numerous options outside the student-edited law reviews. In this way, more faculty-edited journals might alter the marketplace for legal scholarship enough to pressure student-edited law reviews to create more author-friendly publication processes. However, because of the prestige carried by the top tier of student-edited law reviews, it could be quite some time until faculty-edited journals supplant the top student-edited ones, if they ever do.

\section{B. The Faculty-Edited Symposium Format}

Another model of faculty participation, already employed by some journals, is the faculty-edited symposium format. Typically with such a format, faculty editors (sometimes in concert with student editors $^{58}$ ) choose the symposium topic and recruit authors. Editing and production is then left to a student staff. Duke's Law and Contemporary Problems has used this format since its inception. The ChicagoKent Law Review converted to a faculty-edited symposium format in 1987 in a successful attempt to increase the quality and relevance of the review. ${ }^{59}$ According to Professor Lindgren, Chicago-Kent "immediately changed from an obscure, seldom-cited journal to one of the twenty most-cited law reviews (according to Shepard's data). ${ }^{60}$ Professor Lindgren suggests the Chicago-Kent model may be an appropriate solution for law reviews not in the top tier, who cannot compete for legal scholarship in the same ranks as the top-tier journals. ${ }^{61}$

Chicago-Kent's success story is remarkable, and could potentially be replicated by other top-fifty schools with uncompetitive or infre-

fessors. Also, it would be a simple matter for a faculty editor to remove herself temporarily from the selection process if she knew a particular author too well. In short, nepotism is a potential problem in all publishing arenas-it certainly is no more likely at faculty-edited scholarly journals than at student-edited ones.

58. At the Chicago-Kent Law Review, discussed infra notes 59-61 and accompanying text, symposium topics are selected, and publication decisions are made, by a majority vote of a Faculty Oversight Committee consisting of three faculty members, the editor-in-chief, and the managing editor of the Review. See CKLR Executive Board, supra note 8, at 142. Student editors then "handle all the day-to-day responsibilities of the Review without oversight." Id.

59. See generally Barnett, supra note 54 (providing a history of the Chicago-Kent College of Law faculty's decision to convert the law review to a symposium format); CKLR Executive Board, supra note 8 (discussing how the Chicago-Kent Law Review's symposium format works to solve the common problems associated with student-edited law reviews).

60. Lindgren, supra note 1, at 536.

61. See James Lindgren, Reforming the American Law Review, 47 STAN. L. REV. 1123, 1127-28 (1995) (observing that since adopting this new format, the Chicago-Kent Law Review has been cited more frequently). 
quently cited law reviews. However, it is again doubtful that this could provide a global solution to the problems associated with student-edited law reviews. One question that arises is, what about the stand-alone article that, although excellent, is not quite good enough (or does not have a good enough pedigree) to merit an offer from a top-tier law review? In this case, a symposium editor at a less prestigious law review would either need to shoehorn the piece into a symposium, or build a symposium around it. The former approach may hurt the piece, leaving it either altered to fit the symposium, or perhaps overlooked because it is surrounded by a symposium on tangentially related topics. The piece may also hurt the symposium into which it gets wedged if it distracts from the main topic. Alternately, building a symposium from scratch around a strong piece may result in an awkward or thin issue. At any rate, responses to a provocative piece are already provided by the academic community in the form of book reviews, commentary and, most notably, by response articles or essays. In fact, this system is preferable to building ad hoc symposia around strong articles, because reflected responses are in many ways superior to spur-of-the-moment or commissioned replies.

The executive board of the Chicago-Kent Law Review points out several additional problems with their model. First, publication of issues may be delayed because symposia must be held up if a contribution is late. ${ }^{62}$ Second, the addition of faculty editors increases the bureaucracy of the publication process. ${ }^{63}$ Third, as with peer-edited reviews that employ student staff, students may not welcome the loss of control, believing it will reduce the prestige of their journal. ${ }^{64} \mathrm{Fi}$ nally, the symposium model severely limits the number of different topics covered by the review within the one-year tenure of a particular executive board. ${ }^{65}$

\section{Reform of the Submission and Selection Process}

Commentators have suggested that student-edited law reviews reform their selection processes by conducting blind reviews, ${ }^{66}$ by not

62. See CKLR Executive Board, supra note 8, at 143-44 (noting that this delay is also frustrating for authors who submitted their articles early).

63. See id. at 145.

64. See id.

65. See id. at 146 (expressing concern over capturing only one viewpoint).

66. See, e.g., Lindgren, supra note 1 , at 538. 
accepting incomplete or poorly written manuscripts, ${ }^{67}$ and by adopting policies against multiple submissions, which will reduce the manuscript glut. ${ }^{68}$ For various reasons, however, none of these policies is advisable.

Blind review is unlikely to be practical. As the articles editors of the University of Chicago Law Review point out, there are many clues to an author's identity in her submission, even after the byline is removed; acknowledgement notes, textual references to earlier articles by the same author, and even the simple contents of the article may frustrate blind review by revealing the author's identity. ${ }^{69}$ And even if the article review process could be totally blind, other hierarchies will inevitably develop based on available information, with the identical effect of favoring certain articles based on arbitrary characteristics. For example, an article responding to, extending, or extensively citing to articles or arguments published in top journals may be favored, as may an article on a topic that is currently "hot" among the top journals. $^{70}$

Student-editors' willingness to accept partial manuscripts and the manuscript glut are products of the ultra-competitive race to the top of the law review hierarchy engaged in by all student-edited reviews. As I argue above, as a result of this deeply rooted competitiveness, collective action to change current submission procedures is not possible. ${ }^{71}$ The barriers to collective action would also prevent the adoption of blind article review. Any individual law journal is unlikely to adopt blind article review policies due to the perhaps accurate perception that publishing articles by well-known legal scholars is the quickest path up the law review hierarchy.

67. See Sanger, supra note 10, at 524 (suggesting that the pieces meet the entire board's standards at the time of submission); conversation with H. Jefferson Powell, Professor, Duke University School of Law (Apr. 16, 1999).

68. See Jensen, supra note 12, at 385-86 (calling for norms to guide publication behavior).

69. See Articles Editors, supra note 7, at 555.

70. Hot topics may be, for example, rapidly developing areas of law, such as Internet law. See, e.g., David R. Johnson \& David Post, Law and Borders-The Rise of Law in Cyberspace, 48 StAn. L. Rev. 1367 (1996); Lyrissa Lidsky, Silencing John Doe: Defamation \& Discourse in Cyberspace, 49 DuKE L.J. 855 (2000); Paul M. Schwartz, Privacy and Democracy in Cyberspace, 52 VAND. L. REV. 1609 (1999). Hot topics may also involve current controversies in constitutional law, such as state and local government involvement in foreign policy. See, e.g., Michael D. Ramsey, The Power of the States in Foreign Affairs: The Original Understanding of Foreign Policy Federalism, 75 Notre DAME L. REV. 341 (1999); Edward T. Swaine, Negotiating Federalism: State Bargaining and the Dormant Treaty Power, 49 DUKE L.J. 1127 (2000); Symposium, Foreign Affairs Law at the End of the Century: Part II: Role of the States in Foreign Affairs, 70 U. COLO. L. REV. 1223 (1999).

71. See supra Part III.B. 


\section{CONSTRUCTIVE REFORMS}

The suggested solutions discussed in Part IV above-forming more faculty-edited law journals and reforming the submission and selection process-are misguided. Some are simply not feasible given the barriers to the collective action required for meaningful reform of the student-edited law review institution, while others would undermine the significant benefits of student-edited reviews. Many suggested reforms, however, are appropriate and feasible, and would greatly benefit the student-edited law review institution.

\section{A. Diversify the Selection of Members}

One way to increase the quality of editing on student-edited law reviews, which surprisingly none of the commentators I read mentioned, is to diversify the selection criteria for law review membership. The traditional method of selecting merely those rising secondyear students with the highest first-year grades results in a review staffed with the best exam takers in a class. This is decidedly not the best way to select the best candidates for law review work, since citechecking, editing, and legal writing require much different skills than exam taking.

To recruit a more diversified staff, many reviews, including Duke's, accept some members based on grades and some based on a writing competition. ${ }^{72}$ The Duke Law Journal accepts one-third of its staff editors based solely on first-year grades, one-third based on an open-research writing competition score, and the remaining one-third based on a composite of writing score and grades. The Duke Law Journal also holds a write-on competition each spring, in which second-year students may submit a note for publication. Any submissions of publishable quality are accepted, and their authors are offered a position as staff editor for their third year. The Journal normally accepts one or two submissions each year through the writeon competition.

I believe that diversifying membership criteria by including writing, editing, and Bluebooking exercises is very beneficial to a law review. Many of my colleagues on the Duke Law Journal are excellent writers and editors, and it is very likely that some of them would

72. See Leibman and White, supra note 13, at 400-01 (describing various criteria for offers of law review membership and observing that " $[\mathrm{t}]$ he trend appear[s] to be definitely in the direction of increasing reliance on writing competition for selecting law review staff"). 
not have been offered journal membership had the selection process been based solely on grades. Accepting some members based on writing and editing skills is an excellent step toward improving the quality of student editing.

\title{
B. Encourage Informal Faculty Involvement
}

Giving professors authority over law reviews would not be productive; it is unlikely that many professors would be eager to invest the extensive time required to supervise student-edited law reviews, and taking away the autonomy of student editors may adversely affect their performance. ${ }^{73}$ Informal faculty involvement, however, may be very beneficial and may increase the interaction between student editors and in-house faculty. ${ }^{74}$ There is in fact a long tradition of informal faculty involvement with student-edited law reviews. As John Kester recalls, during his tenure with the Harvard Law Review,

\begin{abstract}
professors... generously supplied counsel that we were clever enough to recognize (if not always admit) we needed. I doubt that the practice was vastly different at other schools. True, faculty members acted only by invitation. But the invitations were frequent, and were built into the editorial process-not just to contribute articles, but to comment on manuscripts received, to critique final drafts of student notes, and to suggest worthwhile topics for student writing. ${ }^{75}$
\end{abstract}

Informal faculty involvement in the publication process is an appropriate step toward improving the current system. It leaves editorial control in the hands of student editors, and thus does not upset the perception of student control so crucial to the reputation of a journal. But at the same time, informal faculty involvement does put a check on the selection of borderline articles that sound interesting to a student reviewer, but may not be original or coherent when placed in the context of the existing scholarship by an expert. Problems may arise if faculty assistance leads to an expectation by a professor that the review will "return the favor" by giving his article special consideration. But although expectations of nepotism may be aggravated by requesting favors from faculty, they may still be dealt with diplomatically by a mature editor.

\footnotetext{
73. See supra Parts IV.A-B.

74. See supra Part II.B.

75. Kester, supra note 1, at 14.
} 


\section{Instruct Editors in Editing}

As mentioned above, one of the major problems with studentedited law reviews is the (often total) lack of experience student editors have had with editing. ${ }^{76}$ As a result, student editors frequently over-edit, often "try[ing] to rewrite every sentence." viding student editors with training in editing have been conducted with much success at the University of Texas and the University of Michigan. ${ }^{78}$ Professor Lindgren favors this approach, ${ }^{79}$ and I agree that it is a good idea. Additional training in editing will benefit both authors, whose work will be edited more skillfully and responsibly, and student editors, whose increased editing skills will likely improve the finished product, and thus benefit the reputation of their journal. The logistical problem with this approach, of course, is the difficulty in recruiting faculty members who are willing to assume the additional teaching load. ${ }^{80}$

\section{Make Article Editors Responsible for Editing}

Article editors are the principal liaisons between their journals and the authors whose work they publish. Article editors should take responsibility for ensuring that all communication between the journal and an author regarding the author's work is relevant. Therefore, article editors should review all author queries and all editorial changes made by other editors in the law review hierarchy before the suggested changes are sent to the author.

Funneling all journal-to-author communication regarding the editing of the author's article through the article editor results in a simpler and more coherent editing process from the point of view of the author, who does not need to wonder which editor to contact with questions or concerns about her article. In addition, this strategy eliminates much of the re-opening of settled issues which Professor Sanger mentions. ${ }^{81}$ We employ this strategy at the Duke Law Journal,

\footnotetext{
76. See supra Part I.C.

77. Lindgren, supra note 1 , at 527.

78. See Lindgren, supra note 61 , at $1125-26$ (describing the editorial seminar model).

79. See id. at 1129 (advocating more faculty involvement).

80. See id. at 1126 (noting that giving faculty members additional teaching responsibilities reduces faculty resources for other areas).

81. See Sanger, supra note 10, at 523 (discussing the author's frustration over the multiple demands for revisions made by different editors).
} 
and it seems to cut down significantly on the excessiveness and repetition often associated with serial editing.

\section{E. Return Control of the Work to the Author}

As Professor Sanger observes, "the location of final authority with the author... has been overridden in law [reviews] by more headstrong notions of editorial duty." ${ }^{, 2}$ I believe that it is absolutely improper for any editorial board, whether composed of student, peer, or professional editors, to attempt to override the author's control of the final draft. My own view is that almost all final authority should remain with or be returned to the author. This is, of course, the most radical reform I endorse, and one that will be extremely difficult to promulgate because of the problems with collective action discussed above. ${ }^{83}$ But, given my own experiences as an author in the struggle for control of my own text, I have a strong personal conviction that final authority on the substantive text and the writing style should be returned to the author. After all, it is the author who writes for a living, ${ }^{84}$ and the author, not the law review or the student editor, whose name appears on the byline, who receives credit for the work, and who takes public and professional responsibility for the contents of the article. $^{85}$

I favor giving the authors final authority on virtually all abovethe-line editing and all non-technical below-the-line editing decisions. Exceptions should only be carved out for "house style" for the sake of consistency-issues such as which Latin phrases require italicization and which compound words are hyphenated and which are closed. The format of below-the-line citations should also be presumptively within the student editors' authority, since, like house style, citation form should be consistent within a law review from article to article and from issue to issue. All substantive questions and questions of writing style, however, should be subject to the author's final determination.

Of course, this return of control to the author certainly will not preclude student editors from challenging logical flaws or awkward sentences. Editors still must undertake the responsibility of reading the author's work critically, with an eye to improving it. Most authors

82. Id. at 517 .

83. See supra Part III.B.

84. See Sanger, supra note 10, at 515 (encouraging editors to give deference to authors).

85. See id. at 516 . 
highly value constructive editing suggestions, when made with appropriate deference and respect. However, it is only appropriate that editing suggestions be explicitly labeled and treated as just that-suggestions. Even editing suggestions that the article editor feels most strongly about should always be presented as suggestions for the author to accept or reject as she sees fit-not as instructions or demands.

An easy way to facilitate the author's final review of the editors' suggested changes to her work following the convoluted process of serial editing is to present the author with a redline version of her work, showing every change made since she submitted her own "final version." Using a redline copy as the final review copy is much easier for the author than reviewing a rewritten manuscript with no changes marked, which may little resemble her own work. The author can take notice of every change suggested by the editors, and mark those that she rejects. This use of redline versions for final author review was used by some of the article editors of Volume 48 of the Duke Law Journal. Although this has not yet become formal policy at the Duke Law Journal, my fellow article editors and I have all used redlined documents this year when presenting final versions of articles to authors for their review. ${ }^{86}$

While it will certainly give law review editors pause to surrender some of their control, I believe that this leap of faith will not result in a poorer finished product, as some editors might fear. Passing the editors' myriad editorial suggestions through an intelligent author who understands exactly what she is trying to say in her article will improve the article vastly more than the ghostwriting of a team of generally untrained student editors. In addition, a policy such as the one I suggest above, if publicly adopted by a law review, is likely to draw better and higher-profile authors to the review, since other things being equal (or even nearly equal), any author would prefer to publish in a journal that promised to leave him with editorial control. Thus, the effect of returning control of the text to its author, if accompanied by skillful editing suggestions, reasonably presented, will be to greatly improve the finished product, and with it, the journal's reputation and all-important position in the competitive hierarchy of law reviews.

86. In addition, we have on occasion provided redline versions to authors at their request at earlier stages in the editing process, usually following a particularly invasive edit (such as citechecking). 


\section{CONCLUSION}

Many authors complain that student-edited law reviews are illequipped to evaluate and publish advanced legal scholarship. However, despite their inherent flaws, student-edited law reviews provide substantial benefits to students and faculty. Attempts at reform are complicated by the inherently competitive and hierarchical nature of law reviews and legal culture generally. Some attempts at reform, however, are both workable and highly advisable. I suggest that student editors and faculties interested in improving the quality of student editing and student-edited law reviews broaden the criteria for membership to include writing skills, provide training in editing to student editors, centralize the editing process and author contact with the article editor, encourage informal faculty involvement with certain aspects of law review work such as evaluation of submissions, and return control of the work to its author. These steps should strengthen, not compromise, the finished product of law reviews, which will satisfy authors and student editors alike. 